\title{
The Construction of Yi Chuan's Neo Confucianism from the Perspective of the Distinction between Confucianism and Buddhism
}

\author{
Lei Yi \\ School of Philosophy, Beijing Normal University, Beijing, China \\ Email: 81058259@qq.com
}

How to cite this paper: Yi, L. (2020). The Construction of Yi Chuan's Neo Confucianism from the Perspective of the Distinction between Confucianism and Buddhism. Open Journal of Philosophy, 10, 234-242.

https://doi.org/10.4236/ojpp.2020.102016

Received: March 20, 2020

Accepted: May 18, 2020

Published: May 21, 2020

Copyright $\odot 2020$ by author(s) and Scientific Research Publishing Inc. This work is licensed under the Creative Commons Attribution International License (CC BY 4.0).

http://creativecommons.org/licenses/by/4.0/

\section{(c) (i) Open Access}

\begin{abstract}
The distinction between Confucianism and Buddhism (DCB) was a topic that Yi Chuan and his apprentices often discussed. Criticizing the Buddhism was an important content of Yi Chuan's Neo Confucianism (YNC). The Neo Confucianism of Song and Ming Dynasties was the reaction of Buddhism, and Yi Chuan was one of the founders of the Neo Confucianism. Buddhism philosophy was based on the mind theory, which strengthened Yi Chuan's choice of another way-seeking objective heavenly principles-to build his own philosophy. Another profound philosophical thought of the DCB in YNC was that he tried to use metaphysics to criticize the nihilism of Buddhism. In the process of philosophy transformation in Tang and Song Dynasties (TSD), the YNC was an important weapon to resist the Buddhism nihilism. Therefore, under the background of the transformation of philosophy in TSD, it is necessary to use the method of comparative philosophy to research YNC from the perspective of $\mathrm{DCB}$, so as to further reveal its theoretical construction logic and its philosophical significance.
\end{abstract}

\section{Keywords}

Neo Confucianism, Zen, Metaphysics, Nihilism

\section{Introduction}

There have always been different views about the influence of Buddhism on the Neo Confucianism (NC), among which the two are worth exploring. One is the "internal influence", which is represented by Liang Qi-chao and Chen Yinko (Liang, 1920; Wu, 1998). The second is the "external stimulation", that is to say, 
Buddhism was only an external stimulation for the NC, represented by Mou Zong-san, who stood in the Confucian position, disagreed with the views of Liang and Chen (Mou, 1969). Was the influence of Buddhism on NC external or internal? Was the impact large or small? Generally speaking, it is not convincing. In addition, there were many great philosophers of NC in the Song and Ming Dynasty (SMD), which were different from each other. For example, as far as Yi Chuan is concerned, Mou's view is true, but to what extent Buddhism stimulated Yi Chuan, it needs to be more specific. In the process of criticizing Buddhism, Yi Chuan was indeed inspired by the philosophy of Buddhist mind. From the perspective of the transformation of Philosophy in Tang and Song Dynasties (TSD), with the decline of ZPM, the rise of NC followed, the internal relationship between them is worth pondering. Yi Chuan Neo Confucianism (YNC) was born in the period of philosophy transformation in TSD. The reason why he attached great importance to "the differentiation between Confucianism and Buddhism" (DCB) was directly related to the background. The YNC responded to the challenge of Buddhism, and its DCB contained the criticism of Buddhism, through which he achieved the transcendence of Buddhism. The ZPM was the catalyst for the transformation of philosophy in Tang and Song Dynasties (TPTS). Just under the stimulation of ZPM, Yi Chuan began to pay attention to the research of metaphysics and ontology, thus constructing the metaphysics system of Confucianism. The YNC was an important link in the TPTS. As far as Yi Chuan was concerned, his DCB mainly involved two aspects of Confucianism and Buddhism, and its criticism was not only aimed at Buddhism, but also at the inside of Confucianism. Therefore, it is necessary to study YNC from the perspective of the DCB for further revealing its philosophical significance.

\section{Responding to the Zen's Philosophy of Mind}

Yi Chuan constructed the NC in the process of responding to the ZPM, and the reason why he criticized the ZPM was that it had too much influence at that time. The main achievements of Philosophy in Tang Dynasty (TD) are contained in the localized Buddhism. Although Confucianism, Buddhism and Taoism all developed in this period, the other two religions could not be compared with Buddhism in philosophy innovation. "The whole Li Tang Dynasty, in terms of cultural and ideological level, especially in the development of China's inherent philosophy, does not have much to praise. The ideological height of this era is mainly reflected in Buddhism" (Yang, 2015: p. 1). Chinese Buddhism had been continuously innovating on the basis of long-term absorption and digestion of Indian Buddhism, and in the Sui and Tang Dynasties (STD), which had achieved unprecedented achievements in the philosophy of mind. The Buddhist philosophy of mind was the essence of Buddhism, and its theoretical height and spiritual realm represented the spirit of the times in the STD of China. The main representative of Buddhism was Tiantai, Huayan and Zen. At the end of TD, the ZPM had become the mainstream of the Buddhism philosophy, which was the 
most typical representative of the Buddhism sinicization, and it had the greatest influence on Chinese culture and spirit. Chen Yinko believed that "since the Song Dynasty, Buddhism had entered the marrow of the Chinese people and could not be separated" (Wu, 1998: p. 103). And Liang Qi-chao believed that "the Buddhism of Tang Dynasty (TD) was very prosperous, the Confucianism of Song Dynasty (SD) adopted it in order to build a new philosophy" (Liang, 1920: p. 14). The ZPM was the result of Chinese senior monks' understanding of the India Buddhist scriptures, as well as their theoretical creativity. The reason why the ZPM could represent the highest achievement of Chinese Philosophy in TD was that it had a complete theoretical system, and a profound impact on the production and development of NC in SMD. In the face of the ZPM, Yi Chuan had no choice but to say, "Are there few people who are knowledgeable? In the end, all of them are Zen scholars” (Ming \& Yi, 2004: p. 171). Ming Dao also said: “The ZPM, which everyone talks about today, is filled with monstrous, and its harm is boundless" (Ming \& Yi, 2004: p. 3). It was not the Buddhist belief system of Buddha and Bodhisattva that troubled Yi Chuan and his brother Ming Dao, but the ZPM.

The birth of NC in Song Dynasty (SD) was directly related to the stimulation of Buddhism. The reason why Buddhism, as a foreign religion, could thrive and develop in China was directly related to its localization. Buddhism was good at convenient teaching. By adopting flexible missionary strategies and colorful religious products, it satisfied the belief needs of the emperor and ordinary people. This was the most fundamental reason for its successful spread in China. The difference between Buddhism and other major religions in the world was that although its surface was an inclusive and open system of polytheistic Buddhas, there were in fact many philosophical systems deep into it. And these philosophical systems were the essence of Buddhism. The external polytheistic system was just its gorgeous coat. Although this coat was very important for its spread as religion, once it left its internal philosophical system, the Buddhism also cannot be called Buddhism. Unexpectedly, this phenomenon of inner and outer layers of skin had not affected its development at all. Instead, it catered to the pragmatism spirit in the bones of different classes and different groups in ancient China with its diversity and openness. Continuous sinicization was the root cause of Buddhism's long-term standing in China. After nearly a thousand years of evolution, Chinese Buddhism in the STD had found a continuous sinicization path. In fact, as early as when Kumārajīva translated "Mahāprajnāpāramitāśāstra", he had discovered that Chinese people like simplicity very much, and this discovery in a certain sense heralded a specific path for Buddhism to continue to be Chinese (Kumārajīva, 1991). In other words, he found that the Chinese people pursued the spirit of "the road to simplicity" both in religion and philosophy. The ultimate goal of Buddhism's life was to become "Buddha", and if people want to become "Buddha", they must find the right way. Buddhism declared that they had "Eighty-four thousand methods", including 
worship, offerings, meditations, chanting Buddhas, mantras and precepts, etc. But it was the most puzzling place for people to depend on which method to become a Buddha. Zen Masters firmly believed that they had found the best way to become Buddhas, and only by their practice and mind philosophy could people become Buddhas. From the perspective of Chinese Buddhist history, the practice and philosophy of Zen were indeed the most simple and practical. Zen didn't care how complicated the philosophical theory was, but how to practice it. It was this tendency that made Zen popular. The reason for the rapid rise of Zen Buddhism was largely because it was simple and clear at the two levels of "Zen theory" and "Zen practice", and met the needs of the public in the most direct and convenient way. And all this was based on the ZPM. The ZPM integrated ontology and metaphysics, and constructed a very developed philosophy system. In the view of the ZPM, mind was the origin of the world, and it created the whole world, and the essence of the world was the change of mind. Therefore, the first philosophy of Zen was the research of mind. The essence of the ZPM was metaphysics, and their theoretical focus was ontology. Inspired by the ZPM, Confucianism in SD also began to pay attention to the research of ontology, and took metaphysics as the key direction of research, thus opening up a new situation of Confucianism. Confucianism paid more attention to the study of cosmology in the Han and Tang Dynasty, but changed to the research of ontology in the SD. The reason for such a great change was closely related to the stimulation of the ZPM.

Ying-shih Yu believed, "if we want to take the fundamental orientation of Neo Confucianism seriously, we must put it into the historical dynamic of Confucianism in the SD and make an overall observation in the vertical aspect" (Yu, 2011: p. 920). The problem here is that it is certainly not enough to study "all the Confucianism of Song Dynasty" vertically. If we do not include the BPM in STD, especially the ZPM, into the research object that affected the production of the NC, we cannot fully and well explain the "fundamental orientation". From the perspective of the TPTS, with the decline of ZPM, the rise of the NC followed, the internal relationship between them is worth pondering.

The ZPM was the epitome of the BPM in STD, which pushed the BPM to the top. The great theoretical pressure that Yi Chuan faced in the middle and late Northern Song Dynasty (NSD) mainly came from the ZPM. The reason Yi Chuan wanted to re-examine the pre-Qin Confucianism across the Han and Tang Dynasties (HTD) was that the Confucianism in the HTD had been unable to respond to the challenges of the ZPM. It was precisely in response to the challenge of the ZPM, that Yi Chuan re-integrated the theoretical resources of pre-Qin Confucianism to make it more systematic. He paid more attention to the research of ontology.

\section{Constructing Neo Confucianism}

The emergence of Neo Confucianism in the NSD was a reaction to the ZPM. It could even be said that without the ZPM, there would be no Neo Confucianism. 
Yi Chuan and his brother Ming Dao who were the true founders of Neo Confucianism both were strongly opposed to the ZPM. Their first philosophy was heavenly principle, not mind, which was the biggest difference from Buddhism (Graham, 1958). They criticized that ZPM was the flood and beast, and suggested that people avoid them. In the eyes of Ming Dao, the whole world was full of life, and he believed that life was the embodiment of heavenly principle (Zhang, 2015). He frequently criticized the asceticism of Buddhism with his philosophy of life, and believed that people had no desire unless they were dead. Although Yi Chuan agreed with Ming Dao's philosophy, his research object was more inclined to physical phenomena (Peng, 2016). Yi Chuan firmly believed that there were reasons for the change and development of the world, and these reasons were exactly what he wanted to study. Although Yi Chuan also criticized Buddhism, he didn't oppose the asceticism of Buddhism. Instead, he advocated that if human beings had no desire, and the rest were heavenly principles. At this point, it can be said that he was an asceticist. He paid special attention to the research of ontology, especially to absorb the thought resources of ontology in Pre-Qin Confucianism to build a new Confucian metaphysics. The Ming Dao's philosophy was more inclined to cosmology, while that of Yi Chuan's was more inclined to Ontology. Yi Chuan's first philosophy studied not mind, but the laws behind nature and society, and believed that the same law promoting the development of nature and society. He hoped that by observing nature and contacting society, people could gradually discover those laws. He held that people's understanding of the world was gradual, who couldn't get all the laws about the whole world from one thing, and they needed to know one thing by one. Only if people carried on this way for a long time, they could suddenly get through one day. In addition to observing nature and contacting society, Yi Chuan believed that reading Confucian classics and historical books was also an important way to know truth. He once said to his disciples, "if you want to know, you have to read. Books don't need to be read much, but need to know their core meaning. Look more and don't know the core meaning, that is, bookstores. I was greedy for reading when I was young, but now I have forgot what I had read. It is necessary to ponder the thoughts of the saints, remember them in your brain, and then to do with your strength" (Ming \& Yi, 2004). The influence of Yi Chuan philosophy in the history of Chinese philosophy was greater than that of Ming Dao's. Han Yu, a philosopher of Tang Dynasty, tried to use the Confucian way to fight against the Buddhist, as the flag bearer of the Confucian Renaissance movement in the TD, he made it clear that "I so-called Tao is not to the so-called Tao of Laozi and Buddhism" (Yu, 1986: pp. 802-824). He emphasized exclusion of Buddhism and Taoism, and advocated Confucianism. This kind of painstaking intention not only pointed out the direction for the development of Confucian philosophy, but also raised a problem for the Confucians, that is, how to interpret the Confucian Tao. Before Yi Chuan and his brother Ming Dao, the Confucians often interpreted Tao from the perspective of Qi. Although Wang 
An-shi as the most famous thinker in the NSD thought Tao as the origin of the world, he understood Qi as Tao (Meng, 2001: p. 680). The so-called Qi is similar to today's water vapor and the floating clouds, but it was more subtle than water vapor and the clouds. Ancient Chinese generally believed that Qi was divided into Yin and Yang. In Zhang Zai's opinion, who was another famous thinker in the NSD, there was no emptiness in the universe, which was full of Qi (Zhang, 1978: p. 7). Yi Chuan and his brother are not opposed to Qi as the material of the world, but they believed that Qi was not the origin of the world, what behind Qi was something that dominated the movement of Qi, which was the real origin of the world. Yi Chuan believed that the heavenly principle was more fundamental than Qi. In the history of Chinese philosophy, it was the first time that Yi Chuan and Ming Dao raised the "heavenly principle" to the height of the first philosophy. Only when the Ming Dao and Yi Chuan's Neo Confucianism was formed, did the Confucians' interpretation of the "Confucian way" really compete with the Buddhism and Taoism in metaphysics.

\section{Criticizing the Nihilism of Buddhism}

It was just under the inspiration of BPM that Yi Chuan constructed the metaphysics of Confucianism, and used this metaphysics to criticize BPM. Therefore, another profound philosophical significance of Yi Chuan's DBCB is that he tried to criticize the nihilism of the BPM with the metaphysics of Confucianism. In fact there is a profound nihilism in the BPM, and the so-called nihilism here mainly refers to the core concepts of BPM, such as "all dharmas are illusory". The nihilism of Buddhism and its philosophy of mind always were unified, that was to say, the BPM emboded the spirit of nihilism in essence. In the view of Buddhism, the reason why the world was illusory was that it was the product of the mind, and all that people saw, heard and touched were untrue. Since the world was not true, all kinds of interpersonal relationships based on the world were of course not true. Confucianism was firmly opposed to this philosophy, they believed that the world was real. In the process of philosophy transformation in TSD, YNC was a weapon to resist Buddhism's nihilism. From a philosophical point of view, Yi Chuan's DBCB touched the deep-seated problems of Chinese philosophy. China's nihilism spirit didn't come into being only after Buddhism was introduced into China. As early as in the pre Qin period, the philosophy of Taoism had a strong spirit of nihilism, while the opposite Confucian philosophy reflected a positive spirit of entering the world. Confucians often regarded the stability and peace of the world as their responsibility and obligation. They pursued a higher moral realm and thought that the world could be better through their own efforts. But Taoism, on the contrary, thought that people should obey the laws of nature and do nothing. In the view of Taoism, positive action violated the Tao. These two opposite value orientations played a huge role in the formation of the cultural mind of the ancient Chinese. After Buddhism was introduced into China, which only deepened Chinese nihilism 
spirit, the Tao in the philosophy of the Taoist school dominated all things, which was the real "entity" and also the "subject" that people couldn't control. However, Buddhism was different, which advocated "No Self" and "Dharma Emptiness", there is neither a "subject" nor an "entity" in this world. Taoism held that the world was a real existence, because Tao was the real claim of the world, but Buddhism thought that the world was untrue. According to Buddhism, the worldly Dharma is illusory, just like a dream. Taoism advocated that people should do nothing, and Buddhism adviced that people believe nothing. Hui Neng, a famous Buddhist in TD, held that people could become Buddha in their own mind, and all of the world were born with our own mind. In Taoist's philosophy, although Tao was the master, it left a place for people. If people could always keep clear, calm and inaction, they would find a way to get Tao. But in Buddhism, the view of the human being was quite negative. Life was impermanent, and the purpose of human existence was to get rid of the humanity. Confucianism in SD strongly opposed the nihilism of Buddhism. As a relative of Yi Chuan, Zhang Zai was also a famous philosopher, who tried to criticize the nothingness of Buddhism with the filling of Qi (Wang, 2017). However, Yi Chuan was not satisfied with the idea that Qi as the essence of the world, who thought that the heavenly principle was was the most real existence, so everything in the world based on it (Chen, 2004: pp. 72-79).

Although the ZPM was still based on Prajna classics such as the Vajrayana Sutra, its affirmation of human subjectivity has completely surpassed that of Indian Buddhism. However, it was impossible for Zen to get rid of the nihilism spirit brought by Indian Buddhism. Although people's "subjectivity" had been strongly publicized in Zen, it still exuded a strong sense of nihilism, which could be seen from the understanding of "Buddha Nature". In the view of the ZPM, the "Buddha Nature" often referred to "Emptiness". In Buddhism, the meaning of "Emptiness" is that there is no self nature. Objectively speaking, only relying on Buddhism's own efforts could never get rid of the nihilism. One of the important reasons why Yi Chuan criticized Buddhism's nihilism could gain wide influence was that he could stay outside.

The characteristic of ZPM was that it paid attention to the subjective initiative of "mind", while the characteristic of YNC was that it highlighted the objective reality of "heavenly principle". He tried to overcome the subjective randomness of ZPM by highlighting the objective reality of "heavenly principle". Criticizing the ZPM not only highlighted the dominant position of Confucianism, but also affected the construction of YNC. This influence was mainly reflected in the arrangement of the theoretical system. Yi Chuan regarded the "heavenly principle" as the first philosophy, while the "mind" should follow the "heavenly principle". Therefore, at least from the external form, Yi Chuan reversed the relationship between "mind" and "principle" contained in the Zen. Although Yi Chuan didn't like Zen's position and method, he could not avoid the Zen's "unity of mind and ontology" theory. It was just the mode that he adopted in the deep integration of 
the Confucian traditional thought theory resources. What's more, when Yi Chuan constructed his own theory, he kept the spirit of "objectivity principle" which dominated his NC to the end, and absorbed "mind theory" into the system of NC which was dominated by "objectivity principle". On the one hand, it could restrain the subjective arbitrariness of ZPM, but on the other hand, it also greatly limited the initiative of the mind.

At the same time, it must be pointed out that the nihilistic of the BPM had a profound insight, because this spiritual traceability originates from the impermanent destiny of mankind in the entire universe. Human nihilism has its inevitability, and metaphysics is just a means for humans to resist nihilism. In a sense, this may only be a kind of conceit. Yi Chuan seemed to have found a new basis for his ultimate care through metaphysics, but this basis was likely to be vulnerable. Essentially, any traceability of value relying on metaphysics comes from a human ability, that is, the subjective initiative given to it in a meaningful way. And all of this is obviously illusory from the perspective of Buddhism, as long as man is still a kind of "transient, selfless" existence. In addition, metaphysics itself has the risk of nihilization, that is, metaphysics can choose either a positive direction or a negative direction in terms of value orientation. Although both Confucianism and Taoism advocated "imitating heaven and earth", they had opposite value orientations. This is the proof that different people's metaphysics have different value orientations when they treat the same world. Therefore, Yi Chuan emphasized that the "heavenly principle" was "Truth", which was nothing but one of his belief. Therefore, on the one hand, we must understand both the "essence" of the nihilist spirit, and on the other hand, the "true colours" of the so-called metaphysics.

\section{Conclusion}

Without the stimulation of the ZPM, there would be no YNC. It just was inspired by the ZPM that Yi Chuan focused on the research of Confucianism ontology. He criticized the ZPM and constructed the metaphysics of Confucianism. In this process he gradually brought about the TPTS, and replaced the dominant position of the subjective spirit of ZPM with the "objective principle" of Confucianism. From the history of Chinese Philosophy, it's not accidental that the "subjective spirit" of ZPM was replaced by the objective principle of the NC. In the middle and late period of the NSD, the ZPM had developed to the extreme, and its "subjective spirit" had been perfectly presented, which led to its lack of space for theoretical innovation. Therefore, there is an inherent historical inevitability in the transformation of the philosophy paradigm.

\section{Conflicts of Interest}

The author declares no conflicts of interest regarding the publication of this paper. 


\section{References}

Chen, L. (2004). Neo Confucianism in Song and Ming Dynasties. Shanghai, China: East China Normal University Press.

Graham, A. G. (1958). Two Chinese Philosophers: Cheng Ming-tao and Cheng Yi-chuan. London, England.

Kumārajīva (1991). Mahāprajnāpāramitāśāstra. Shanghai, China: Shanghai Classics Publishing House.

Liang, Q. C. (1920). An Introduction to Academic Research of Qing Dynasty. Shanghai, China: Shanghai Science and Technology Literature Publishing House.

Meng, W. T. (2001). The Ten Kinds of Taoism Books Series. Chengdu, China: Bashu Publishing House.

Ming, D., \& Yi, C. (2004). Two Cheng Collections. Beijing, China: Zhonghua Book Company.

Mou, Z. S. (1969). The Essence of Mind and The Essence of Human Nature. Changchun, China: Jilin Publishing Group Co., Ltd.

Peng, Y. G. (2016). Research On Similarities and Differences of Ercheng's Neo Confucianism. Jinan, China: Shandong People's Publishing House.

Wang, X. Q. (2017). Based on Qi and Based On Principle. Beijing, China: China Social Sciences Press.

Wu, M. (1998). Wu Mi's Diary (Volume II, December 14, 1919). Beijing, China: Sanlian Bookstore.

Yang, L. H. (2015). Fifteen Lectures on Neo Confucianism in Song and Ming Dynasties. Beijing, China: Peking University Press.

Yu, H. (1986). Collected Works of Han Yu. Shanghai, China: Shanghai Classics Publishing House.

Yu, Y. S. (2011). Zhu Xi's Historical World. Beijing, China: Sanlian Bookstore.

Zhang, M. H. (2015). Ceaseless Tao and Sages' Style. Beijing, China: China Social Sciences Press.

Zhang, Z. (1978). Zhang Zai Collection. Beijing, China: Zhonghua Book Company. 